\title{
Coriandrum sativum (Coriander) in Oral Health: Literature Review
}

\author{
Coriandrum sativum (Coentro) na Saúde Bucal: Revisão de Literatura
}

\author{
Cristina Tiemi Hanashiro ${ }^{\text {a }}$ Alejandra Hortencia Miranda González*ab \\ ${ }^{a}$ Unopar, Department of Restorative Dentistry, PR, Brazil

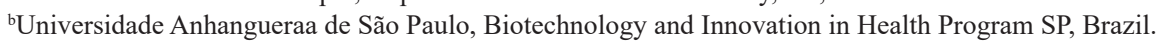 \\ *E-mail: alejandra.horten@anhanguera.com
}

\begin{abstract}
Mouthwashes are an effective complementary method in the biofilm prevention and chemical control, when the practice of mechanical removal is insufficient. Among the active compounds most used in antiseptics are chlorhexidine, cetylpyridinium chloride, triclosan and essential oils. In order to reduce undesirable effects, such as teeth and restorations staining and the supragingival calculus formation, observed mainly after use for long periods, natural products of plant origin have been extensively studied and incorporated into oral hygiene formulations. Commonly used as a functional food or spice in world gastronomy, Coriandrum sativum (C. sativum), popularly known as coriander, is a natural therapeutic resource with several properties, including antifungal and antioxidant ones. Thus, the objective of this study was to carry out a literature review of articles published in the last 10 years that relate natural products, dentistry and C. sativum, in order to understand the role of naturally-occurring agents with potential therapeutic applications in the dental fields, as well as to evaluate the application of $C$. sativum in the treatment of oral diseases. Therefore, a bibliographic search was carried out in the ScienceDirect and PubMed databases, obtaining 20 articles. It was possible to confirm the antifungal properties and the mode of action of the essential oil from C. sativum in Candida species, as well as its relatively low cytotoxicity in human cells. These findings should encourage further studies for the development of mouthwashes based on C. sativum as an alternative to mouthwashes available on the market.
\end{abstract}

Keywords: Dentistry. Biological Products. Coriandrum. Oral Health.

\section{Resumo}

Os enxaguatórios bucais constituem um método complementar eficaz na prevenção e controle químico do biofilme, quando a prática de remoção mecânica se mostra insuficiente. Dentre os compostos ativos mais utilizados em antissépticos estão a Clorexidina, o cloreto de cetilpiridineo, o triclosan e os óleos essenciais. Buscando a diminuição de efeitos indesejáveis, como manchamento de dentes e restaurações e a formação de cálculo supragengival, observados principalmente após a utilização por longos períodos, produtos naturais de origem vegetal têm sido amplamente estudados e incorporados nas formulações para higiene bucal. Comumente utilizado como alimento funcional ou especiaria na gastronomia mundial, o Coriandrum sativum (C. sativum), popularmente conhecido por coentro, apresenta-se como um recurso terapêutico natural com diversas propriedades, incluindo antifúngica e antioxidante. Assim, o objetivo deste estudo foi realizar uma revisão de literatura de artigos publicados nos últimos 10 anos que relacionam produtos naturais, a odontologia e o C. sativum, a fim de compreender o papel de agentes de ocorrência natural em aplicações terapêuticas potenciais na área odontológica, bem como avaliar a aplicação do C. sativum no tratamento de doenças bucais. Para isso foi realizada uma busca bibliográfica nas bases de dados ScienceDirect e PubMed, obtendo-se 20 artigos. Foi possivel confirmar as propriedades antifúngicas e o modo de ação do óleo essencial de C. sativum em espécies de Candida, bem como sua citotoxicidade relativamente baixa em células humanas. Esses achados devem incentivar novos estudos para o desenvolvimento de enxaguatórios bucais baseados em C. sativum como alternativa aos enxaguatórios bucais disponíveis no mercado.

Palavras-chave: Odontologia. Produtos Biológicos. Coriandrum. Saúde Bucal.

\section{Introduction}

The World Health Organization defines herbal medicines as materials or products derived from plants with therapeutic or other human benefits, containing raw or processed ingredients from one or more plants ${ }^{1}$, and estimates that $60 \%$ of the world population and $80 \%$ of the population in developing countries trust and use these drugs for primary health care ${ }^{2}$.

In fact, secondary metabolites from plants, microorganisms and marine products are valuable sources of new molecules for drug development in numerous biomedical areas. And for a long time, humanity has benefited from the use of natural products to treat or prevent a wide spectrum of diseases, including those of oral origin ${ }^{3}$.

In addition to conventional drugs derived or inspired by natural products, formulations available without prescription, such as toothpastes and mouthwashes, also feature plant extracts or essential oils in their composition for therapeutic purposes or as flavoring agents ${ }^{4}$.

Mouthwashes are an effective complementary method in the biofilm chemical control, when the practice of mechanical removal is insufficient, and constitute an important vehicle for the antimicrobial agents administration, helping to prevent 
carious injuries ${ }^{5}$.

With the growing concern in health and beauty, and the interest in natural products, a demand for new products with improved functional ingredients has been created. In this context, essential oils play an important role as bioactive ingredients with antimicrobial, antioxidant, antiinflammatory properties and are used in a variety of cosmetics, phytotherapeutic and pharmaceutical products ${ }^{6}$.

Commonly used as a functional food or spice in world gastronomy, Coriandrum sativum or coriander is a natural therapeutic resource due to the various properties observed. One of its most explored applications is the food preservation with a natural base, which aims to prolong the shelf life of food, slowing down the oxidation process and food microbial deterioration ${ }^{7}$.

Studies with Coriandrum sativum extract and its bioactive phytochemicals report a range of biological activities, including antioxidant, anticancer, neuroprotective, anxiolytic, hypnotic, anticonvulsant, analgesic, anti-inflammatory and antidiabetic. These biological activities are mediated mainly by the antioxidant property of its main compound, linalol ${ }^{8}$.

Additionally, other studies have revealed that the essential oil of Coriandrum sativum has relatively low cytotoxicity, and that due to its high antifungal activity, it is a potential candidate in the treatment of oral diseases, such as candidiasis related to the use of prostheses ${ }^{9}$.

It is important to remember that the extraction and composition of plant products must be properly carried out under controlled and regulated methods to obtain accurate and reproducible data ${ }^{4}$.

From what has been stated above, the main objective of the present study was to perform a review of the application of natural products in dentistry, focusing on the possibility of using Coriandrum sativum in the treatment of oral diseases.

\section{Development}

\subsection{Methodology}

A bibliographic search was performed in the ScienceDirect platform and PubMed databases, using the English descriptors "Natural products" and "Dentistry" and "Coriandrum sativum", obtaining 20 articles, including articles published in English and Portuguese, which addressed the effect of naturally-occurring agents with potential therapeutic application in the medical and dental fields and the antifungal effect from Coriandrum sativum against Candida species.

\subsection{Literature Review}

The term "natural products" is commonly associated with secondary metabolites produced by an organism, which function as a defense mechanism against herbivores, microorganisms, insects or plant competition. Plants can produce more than 100,000 secondary metabolites, and the total number of plants is estimated to exceed $500,000^{10}$.
Of the 1,184 chemical entities identified between 1981 and 2006 , about $48 \%$ were natural products, semi-synthetic analogs or synthetic compounds based on natural products. And more than $70 \%$ of the therapeutic agents developed between 1981 and 2006 for the treatment of infectious diseases, of bacterial and fungal origin, were derived from natural products ${ }^{10}$.

From 1800 to the first half of 2015, more than 101 million organic and inorganic molecules were cataloged in the world, many of which were produced by natural, synthetic and biosynthetic mechanisms of chemical engineering. And in fact, metabolites from plants, microorganisms and marine products are valuable sources for the development of new drugs $^{3}$.

Therefore, natural products play an important role in pharmacological research and in the development of drugs for the treatment and prevention of diseases, contributing continuously to the expansion of the therapeutic chemical $\operatorname{arsenal}^{11}$.

It is difficult to say precisely when and where plants were used for medicinal purposes for the first time. It is known that the use of plants in the treatment of diseases was already present in the first civilizations. However, only from written records is it possible to trace a history of the use of medicinal plants $^{12}$.

Evidence indicates the use of plants around 60,000 years ago, when remains were found surrounded by at least seven medicinal plants, in a cemetery in northern Iraq. Since then, records on the medicinal properties of several plants have been highlighted, including formulas and vegetable preparations written on clay stones. The preparations were used in the treatment of various disorders or in sacred rituals, and the beliefs and practices were adapted according to each civilization ${ }^{4}$.

In addition to their direct use as a therapeutic agent, medicinal plants are an important raw material for the synthesis of new drugs. It is estimated that approximately $40 \%$ of the available medicines were developed directly or indirectly from natural sources, $25 \%$ of which came from plants. Among the 252 drugs considered basic and essential by World Health Organization, $11 \%$ are from plants ${ }^{13}$.

Brazil is the country that holds most of the biodiversity, about 15 to $20 \%$ of the world's total. Among the elements related to biodiversity integration, plants are the main source of raw material for the manufacture of herbal medicines and other medicines. In addition, plants are also used as home remedies in popular practices, a process known as traditional medicine, whose knowledge is passed on from generation to generation $^{13}$.

Currently, many factors have contributed to the increased use of medicinal plants, among them the collateral effects resulting from the prolonged use of industrialized medicines and the tendency to use integrative medicine and holistic 
approaches to the concepts of health and well-being ${ }^{12}$.

One of the products of the medicinal plants secondary metabolism are essential oils (EO), which have a diversified composition, derived mainly from two groups of compounds, terpenoids (monoterpenes and sesquiterpenes) and phenylpropanoids, which confer antimicrobial and antifungal properties. The effectiveness of the action against a wide variety of bacteria and fungi, including oral pathogens, made the use of plants as an alternative medicine receiving the attention of the scientific community and becoming a promising field in the treatment of pathogens ${ }^{14}$.

Among the approximately 100,000 known secondary metabolites, EO represent more than 3000, in which approximately 300 have aroused commercial interest and are used by the food, cosmetic and pharmaceutical industries ${ }^{15}$.

EO are used in the composition of fragrances, in the food industry as flavoring additives and in several other products as aromatic agents. Currently, studies show a variety of benefits to oral health, making EO promising agents in the treatment of oral diseases and other infections ${ }^{16}$.

Eucalyptol, which is an active ingredient in eucalyptus oil (Myrtaceae), showed activity against C. albicans biofilms and specific activity against periodontal and cariogenic bacteria, such as $P$. gingivalis, A. actinomycetemcomitans, Fusobacterium nucleatum, S. mutans and S. sobrinus ${ }^{17}$.

Popularly known as coriander, Coriandrum sativum ( $C$. sativum) is a small plant belonging to the Apiaceae family and has its origin in the Eastern Mediterranean ${ }^{9}$. According to records of the Egyptian Papyrus, the Ebers Papyrus, around 1600 BC the $C$. sativum was already employed in the synthesis of medicines ${ }^{12}$. Mainly used as a spice in world gastronomy, C. sativum also acts as a natural antioxidant agent aiming to preserve and prolong the shelf life of commercialized foods, delaying the process of oxidation and microbial deterioration ${ }^{7}$.

In traditional medicine, $C$. sativum is widely used in the treatment of various diseases such as rheumatism, neuralgia, gastric complaints, bronchitis, diarrhea, dyspepsia and vertigo. Some studies attribute the plant antibacterial, antifungal properties and the ability to eliminate free radicals and lipids by oxidation. In addition, studies report that leaf extracts, due to their phytochemical constituents, may have more potent effects compared to seeds ${ }^{18}$.

\subsection{Discussion}

The use of natural products in dentistry dates back thousands of years. Salvadora persica, for example, originally from India, was initially used by the Babylonians as an extract or toothpick and gained popularity in 5000 BC. Even today it is widely used in many Muslim and developing countries, mainly due to its low cost. In addition to having an antimicrobial effect, its effectiveness was related to the ability to inhibit the adhesion of Streptococcus mutans to epithelial cells and protection against the calculus formation ${ }^{19}$.

Sticks made from roots, branches or stems, can be found in local markets in Asia and Africa. The sticks are soaked in water for a few hours to soften the fibers giving them the appearance of bristles. In addition to Salvadora persica, other plants are used, such as Diospyros lycioides (blue shrub), Acacia melifera (black thorn), Jasminum fluminense (starry wild jasmine) and Azadirachta indica (neem) ${ }^{5}$.

The addition of plant extracts can also be seen in toothpastes. Tea tree oil, mint, cloves, anise and olive leaves due to antimicrobial action, and extracts of neem leaves and Salvadora persica for their effectiveness in inhibiting various bacteria. Aloe ferox was introduced in the formulation of toothpaste for individuals with sensitive teeth, ulcers and bleeding gums. Also, xylitol and stevia are used as antimicrobials ${ }^{5}$.

Another application of medicinal plants is in the composition of mouthwashes. The first record was identified in China in 2700 BC used to treat gum disease. Currently, they are presented as vehicles to supply chemical agents and as a daily measure in the biofilm control associated with mechanical methods ${ }^{19}$.

The botanical species Achillea millefolium, commonly known as yarrow, when added to the routine mouthwash, administered to cancer patients, proved to be effective in the treatment of oral mucositis caused by chemotherapy, significantly reducing the lesions severity or curing them by complete at the end of the experiment ${ }^{20}$.

Many commercially available mouthwashes contain vegetable ingredients, such as green tea, garlic, thymol, eucalyptol and licorice. The green tea extract acts as an antimicrobial and antioxidant agent, in addition to replacing alcohol, eliminating possible oral irritations. Garlic juice helps to reduce biofilm formation and helps prevent tooth decay, while other plant extracts have recognized antibacterial properties $^{5}$.

The EO from citronella (Cymbopogon nardus), whose chemical compounds are considered antiseptic, demonstrated phytotherapeutic potential with antibacterial and antifungal action, and was effective in controlling biofilm as a constituent of mouthwash. In addition, it showed less cytotoxic effects after serial dilution, considering the concentrations of the active ingredients in commercial mouthwashes to which it was compared ${ }^{16}$.

Although they have variations in their chemical composition, the essential oils obtained from both the leaves and seeds of $C$. sativum are used as cholesterol-lowering agents, digestive stimulants and antihypertensives. In addition, some studies have also revealed antioxidant, hepatoprotective and anticonvulsant activities ${ }^{9}$.

The therapeutic values of $C$. sativum result mainly from the antioxidant property of its main compound, linalool. However, the types and quantity of bioactive compounds can vary according to some factors, such as stage of plant development, geographic region, form of cultivation, processing, storage conditions, and extraction methods ${ }^{8}$. 
The EO from $C$. sativum leaves have strong antifungal and antiadherent activity against Candida spp., as well as anti-proteolytic activity against $C$. albicans. Furthermore, pharmacogenomic analyses revealed that $C$. sativum EO have relatively low cytotoxicity, with putative mechanisms through modulation of gene expression in chemokine and mitogenactivated protein kinase pathways (proliferation/apoptosis), as well as expression of adhesion proteins?.

Although chlorhexidine is considered the gold standard among mouthwashes, due to its high antimicrobial activity, substitutes should be considered due to the adverse effects associated with prolonged use, such as staining teeth, taste alteration, mucosal peeling and stomatitis. Or when there is an indication of use for children or individuals with special needs who may accidentally ingest the rinsing solution ${ }^{19}$.

\section{Conclusion}

Natural products have been proposed as new therapeutic agents in order to minimize the adverse effects of synthetics, and to present effective and safer alternatives for the treatment and prevention of oral diseases Although there are no studies in the literature demonstrating the clinical success of mouthwashes based on C. sativum, it is possible to confirm the antifungal properties and mode of action of the Coriandrum sativum EO on Candida spp. Analyses also revealed that C. sativum EO have relatively low cytotoxicity on human cells. These findings should encourage further studies for development of mouthwashes based on C. sativum as an alternative to commercially available mouthwashes.

\section{References}

1. World Health Organization. Programme on Traditional Medicine. Legal status of traditional medicine and complementary/alternative medicine: a worldwide review. Geneva: WHO; 2001.

2. World Health Organization. WHO global report on traditional and complementary medicine 2019. Geneva: WHO; 2019.

3. Freires IA, Rosalen PL. How natural product research has contributed to oral care product development? A critical view. Pharm Res 2016;33(6):1311-17. doi:10.1007/s11095016-1905-5

4. Gianennas I, Sidiropoulou E, Bonos E, Christak E, FlorouPaneri P. The history of herbs, medicinal and aromatic plants, and their extracts: Past, current situation and future perspectives. In: Florou-Paneri P, Christak E, Gianennas I. Feed Additives: aromatic plants and herbs in animal nutrition and health. London: Academic Press; 2020. p.1-18. doi: https://doi.org/10.1016/B978-0-12-814700-9.12001-1

5. Bodiba D, Szuman KM, Lall N. The role of medicinal plants in oral care. In: Lall N. Medicinal Plants For Holistic Health And Well-Being. London: Academic Press; 2018. p.183-212. doi: https://doi.org/10.1016/B978-0-12-812475-8.00006-8

6. Farias JM, Stamford TCM, Resende AHM. Mouthwash containing a biosurfactant and chitosan: An eco-sustainable option for the control of cariogenic microorganisms. Int J Biol Macromol 2019;129:853-860. doi:10.1016/j. ijbiomac.2019.02.090
7. Silva F, Domeno C, Domingues FC. Coriandrum sativum L.: characterization, biological activities, and applications. In: Preedy VR, Watson RR. Nuts and Seeds in Health and Disease Prevention. London: Academic Press; 2020. p.497-519. doi: https://doi.org/10.1016/B978-0-12-818553-7.00035-8

8. Prachayasittikul V, Prachayasittikul S, Ruchirawat S, Prachayasittikul V. Coriander (Coriandrum sativum): A promising functional food toward the well-being. Food Res Int 2018;105:305-23. doi:10.1016/j.foodres.2017.11.019

9. Freires IA, Murata RM, Furletti VF, et al. Coriandrum sativum L. (Coriander) essential oil: antifungal activity and mode of action on Candida spp., and molecular targets affected in human whole-genome expression. PLoS One 2014;9(6):e99086. doi: 10.1371/journal.pone.0099086

10. Jeon JG, Rosalen PL, Falsetta ML, Koo H. Natural products in caries research: current (limited) knowledge, challenges and future perspective. Caries Res 2011;45(3):243-63. doi:10.1159/000327250

11. Newman DJ, Cragg GM. Natural Products as Sources of New Drugs from 1981 to 2014. J Nat Prod 2016;79(3):629-61. doi:10.1021/acs.jnatprod.5b01055

12. Conselho Regional de Farmácia do Estado de São Paulo. Plantas Medicinais e Fitoterápicos. São Paulo: CRF-SP; 2019.

13. Brasil. Ministério da Saúde. Política nacional de plantas medicinais e fitoterápicos. Brasília: MS; 2016.

14. Bersan SM, Galvão LC, Goes VF, et al. Action of essential oils from Brazilian native and exotic medicinal species on oral biofilms. BMC Complement Altern Med 2014;14:451. doi:10.1186/1472-6882-14-451

15. Freires IA, Denny C, Benso B, de Alencar SM, Rosalen PL. Antibacterial activity of essential oils and their isolated constituents against cariogenic bacteria: a systematic review. Molecules 2015;20(4):7329-58. doi:10.3390/ molecules20047329

16. Guandalini Cunha B, Duque C, Sampaio Caiaffa K. Cytotoxicity and antimicrobial effects of citronella oil (Cymbopogon nardus) and commercial mouthwashes on S. aureus and C. albicans biofilms in prosthetic materials. Arch Oral Biol 2020;109:104577. doi:10.1016/j. archoralbio.2019.104577

17. Kouidhi B, Al Qurashi YM, Chaieb K. Drug resistance of bacterial dental biofilm and the potential use of natural compounds as alternative for prevention and treatment. Microb Pathog 2015;80:39-49. doi:10.1016/j.micpath.2015.02.007

18. Sreelatha S, Inbavalli R. Antioxidant, antihyperglycemic, and antihyperlipidemic effects of Coriandrum sativum leaf and stem in alloxan-induced diabetic rats. J Food Sci 2012;77(7):T119-T123. doi:10.1111/j.17503841.2012.02755.x

19. Jassoma E, Baeesa L, Sabbagh H. The antiplaque/ anticariogenic efficacy of Salvadora persica (Miswak) mouthrinse in comparison to that of chlorhexidine: a systematic review and meta-analysis. BMC Oral Health 2019;19(1):64. doi:10.1186/s12903-019-0741-5

20. Miranzadeh S, Adib-Hajbaghery M, Soleymanpoor L, Ehsani M. Effect of adding the herb Achillea millefolium on mouthwash on chemotherapy induced oral mucositis in cancer patients: A double-blind randomized controlled trial. Eur J Oncol Nurs 2015;19(3):207-13. doi:10.1016/j. ejon.2014.10.019. 